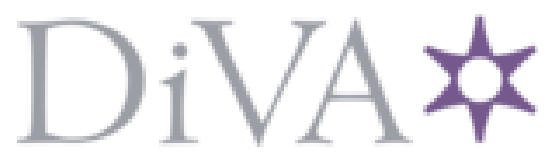

http://www.diva-portal.org

This is the published version of a paper published in Revue des études slaves.

Citation for the original published paper (version of record):

Kotkina, I. (2013)

Soviet Empire and Operatic Realm: Stalinist Search for the Model Soviet Opera.

Revue des études slaves, 84(3-4): 505-518

Access to the published version may require subscription.

N.B. When citing this work, cite the original published paper.

Permanent link to this version:

http://urn.kb.se/resolve?urn=urn:nbn:se:sh:diva-23356 


\section{REVUE}

\section{DES ÉTUDES SLAVES}

TOME QUATRE-VINGT-QUATRIÈME

Fascicule 3-4

Musique et opéra

en Russie et en Europe centrale

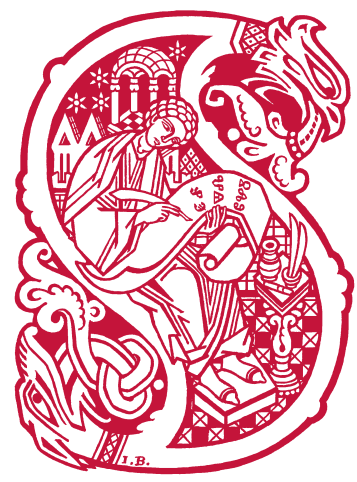

PARIS 


\title{
SOVIET EMPIRE AND OPERATIC REALM STALINIST SEARCH FOR THE MODEL SOVIET OPERA
}

\author{
IRINA KOTKINA \\ Russian State University for Humanities, Moscow
}

This paper analyzes the phenomenon of classical opera used (and abused) by the Soviet officials as an instrument to re-build imperial common consciousness on a new, Soviet ground and, thus, create the transnational political space of a very special character. The history of development of opera as a scenic genre in Russia could be roughly divided into two phases: first - Europeanization of Russian musical culture; and second, in the last half of the 19th century, Russification of what was considered a pure western, court genre by the efforts undertaken by national composers. By the time of advent of Communist regime opera houses still remained local international microcosm, with cosmopolitan orientation in its productions.

This paper studies the changing attitude of the Soviet power to operatic cultural space from total negation in early 1920 s to patronage and support in 1930 s. As soon as the power started to perceive opera as a genre that gives selflegitimization to the regime, it began to spread opera culture all over the space of the multi-ethnic and multi-national Soviet state. The campaign for opening new opera houses in Asian and Caucasian Soviet republics, in big cities of Siberia and Ural started in the 1930s and continued after the end of the Second World War. Very careful attention will be given to the so called 'Decades of the National Art' or Dekady (in Russian), ten days festivals, which represented the operatic and music accomplishments of the 'sister republics' at the stage of the Bolshoi Theater from 1936 till Stalin's death. The paper raises the questions of what was the ideological purpose and background of this campaign and to what extent it made distant areas of the country more dependent on the center.

In a general sense regional centers of classical opera that appeared on a large map of the Soviet Union in late 1930s could ideologically serve as supplementary binds that tied and equalized culturally diverse population of the Eurasian 
Empire stronger than direct political commands and reliably than constitutional laws. It created common Soviet identity that was the core aim of regime's cultural politics.

\section{A FRAGMENT OF PURE ARISTOCRATIC CULTURE}

The Imperial court ceased to be a main source of financial support for opera following the abdication of Nicholas II in March 1917. ${ }^{1}$ From 1917 onwards opera was forced to seek new resources. Operas' priority, as was the case with the majority of Russian theatres at that time, was to survive.

The academic theatres experienced a dramatic transformation of their administrative system between 1917 and 1920. In 1917 the former Imperial theatres (including the Bolshoi and the Mariinsky) secured themselves autonomous self-management and were administered not by a centralized state management bureau - Kontora imperatorskix teatrov - but, in a decentralized manner, by the elected representatives of each theatre's artistic and assisting staff. The project of autonomy had been considered by the personnel of the theatres before, but came into being only after the Revolution. The outcome of this measure was in the Soviet case total anarchy and disorder. Primarily this was because the theatres, due to the economic collapse in Soviet Russia, could not earn enough profit, and the seasons after 1917 and before 1920 in the Bolshoi Theater ended up as financial failures. ${ }^{2}$

The nationalization of the theaters and the establishment of patronage over opera were thereby a logical result of the impossibility of self government against a background of economic deprivation and civil war. The decree of 9 (22) November 1917 put all the theaters under state supervision and the decree of 26 August 1919 eventually nationalized them. Opera, being a very expensive art form, had no way to survive except by resorting to the help and protection of the newly-born Soviet state.

There were two tendencies in the Party leadership as far as opera was concerned. Proletkult ${ }^{3}$ embodied the first tendency that was against traditional

1. See for details: Richard G. Thorpe, The Management of culture in Revolutionary Russia : the Imperial theaters and the state, 1897-1928, unpublished doctoral dissertation, Princeton, Princeton University, 1990; Patrick George Friel, Theater and revolution: the struggle for theatrical autonomy in Soviet Russia, 1917-1920, Chapel Hill [N.C., s.n.], 1977.

2. Archive of the Bolshoi Theater Museum, fond 'Economics and Management, 1917-1928', ed. xr. 64, p. 13-14.

3. 'Proletkult is a portmanteau of "proletarskaja kul'tura" (пролетарская культура), Russian for "proletarian culture". It was a movement active in the Soviet Union in 1917/1925 to provide the foundations for a truly proletarian art devoid of bourgeois influence. Its main theoretician was Aleksandr Bogdanov (1873-1928) who saw the Proletkult as a third part of a trinity of revolutionary socialism. Where the unions would attend to the proletariat's economic interests and the communist party, their political interests, the Proletkult would look after their cultural and spiritual 
opera. It believed that the culture of the new Soviet state should be created by proletarians, be about proletarians and be for proletarians. The more radical elements of Proletkult regarded opera as a bourgeois and aristocratic art-form that should be discarded. The demand for money to be spent on raising the cultural level of the masses was also an argument against funding opera.

Lunačarskij, ${ }^{4}$ the first Soviet Commissar of Enlightenment, helped Bogdanov to found Proletkult and supported its ambitions to develop proletarian culture. But, as Sheila Fitzpatrick argues, ${ }^{5}$ Lunačarskij, from the very beginning, had views of his own and understood his role as a protective one. At times, Lunačarskij found himself in bitter disagreement with Lenin, who rejected the basic notion of Proletkult. ${ }^{6}$ Lenin argued that Soviet culture should be built on the achievements of the past - including aristocratic and bourgeoisie culture. But Lenin was inclined to accept the argument that mass culture (literacy) should have priority over the funding of the Bolshoi and other opera houses in circumstances of great privation. In an attempt to stabilize the economy after the conclusion of the Civil War, the government cut funds for all cultural projects, except the fight against illiteracy. At that time a project came about to close the former Imperial opera theaters. The left of the Communist Party manifested general hostility to traditional opera as a form of aristocratic and bourgeois art. Lunačarskij recorded:

Vladimir Il'ič's attitude towards the Bolshoi Theater was rather anxious... He insisted that its budget be cut and said, 'It is awkward to spend a lot of money on such a luxurious theater... when we lack simple schools in the villages. ${ }^{7}$

To Lenin, the Bolshoi symbolized 'a fragment of pure aristocratic culture,' and he protested against the 'pompous court style' of the opera in $1920 .^{8}$

life. Other influential figures include Anatoly V. Lunacharsky (1875-1933), Aleksey Gastev, Fedor Kalinin and Mikhail Gerasimov; plastic arts were influenced initially by constructivism, literature and music by futurism; with reference to Lenin (On proletarian culture, 1920) experimental art was disapproved.' (From Oliver Stallybrass, Alan Bullock, The Fontana Dictionary of modern thought, Waukegan, Fontana press, 1988, p. 198). See also: Lynn Mally, Culture of the future: the Proletkult movement in revolutionary Russia, Berkeley, University of California Press, 1990.

4. Sheila Fitzpatrick, The Commissariat of Enlightenment: Soviet organization of education and the arts under Lunacharsky, October 1917-1921, Cambridge, UK, Cambridge University Press, 1970.

5. Id., The Commissariat of Enlightenment: Soviet organization of education and the arts under Lunacharsky, 1917-1921, London - New York, 1970/1.

6. See: Mally, Culture of the future...

7. « Ленин и исскуство », in: V. I. Lenin, О литературе и искусстве, Moskva, Goslitizdat, 1957, p. 589.

8. A. V. Lunačarskij, « Ленин об исскустве », in: id., Воспоминания и впечатления, Moskva, Sovetskaja Rossija, 1968, p. 195. 
In a conversation with Klara Zetkin, Lenin said:

While in Moscow perhaps 10,000 people will come to the theater, there are millions trying to learn how to write their name, how to count... We do not have enough schools... ${ }^{9}$

Like the majority of Bolshevik leaders, Lenin had relatively conservative views in matters of arts, but was a great admirer of Wagner. ${ }^{10}$ Lunačarskij's patronage of the academic theaters then was a little bit more acceptable than his support of Futurism.

It was Lunačarskij's accomplishment that cultural institutions such as the Bolshoi Theater remained open after the Revolution. Lunačarskij guaranteed the former Imperial theaters their autonomy by taking direct responsibility for the supervision of their stages. Thus, the Theater Division of Narkompros (TEO) was denied jurisdiction over the traditional stages - the Moscow Art Theater, the Bolshoi and the Mariinsky. Lunačarskij wrote:

The representatives of TEO, fanatics in their work - which is good and laudable - do not have the background to correctly evaluate the importance of preserving the tradition of an already-established culture. ${ }^{11}$

Lunačarskij definitely understood that importance. Already in 1920s the Bolshoi Theater enjoyed very special attention of the authorities and Lunačarskij spoke about its as excellent academy for creating the new Soviet opera on the basis of pre-revolution cultural heritage. ${ }^{12}$ Thus, the demand for the new Soviet classical opera was pronounced almost simultaneously with the creation of the Soviet State.

\section{WE NEED OUR SOVIET CLASSICAL OPERA}

The elevation of opera into one of the most important and prestigious artforms in the USSR was a quite extraordinary transformation. The attitude of the party leadership was crucial in this regard. They could have decided to marginalize opera, but they took, instead, the opposite course and promoted it. As with ballet, literature and music, opera identified Russia as a European and world cultural center. By the revolution opera was already bound up with the prestige

9. Klara Zetkin, Reminiscences of Lenin, London, 1929, p. 14.

10. Robert Service in his Lenin: a biography, Macmillan, 2000, p. 136-137 cites the reminiscences of N. K. Krupskaja and notes 'Lenin was a passionate admirer of Richard Wagner who was an Ulyanov family favorite. He went to hear renditions of his operas as an active listener; he could not bear to sit passively and let the music wash through him. Sometimes the effort disturbed him emotionally to such an extent that he walked out after the first act'.

11. Cited in Abram Gozenpud, Русский советский оперный театр : 1917-1941, Leningrad, Muzyka, 1963, p. 26.

12. See: A. V. Lunačarskij, О музыке и музыкальном театре: статьи, речи, доклады, письма, документы, vol.1, Moskva, Iskusstvo, 1981. 
of the state, and the prestige of local centers - Moscow and St Petersburg. The Bolsheviks were very sensitive to the charge that they were uncouth barbarians. The promotion of opera was related to the notion of the Bolshevik's 'cultural capital': the idea that they were defenders of high art. The promotion of opera was also connected to the raising of the cultural level of the masses, of bringing world cultural achievements within easy reach of the common man and woman. By the 1930s Stalin recognized opera as a highly accomplished art-form and saw it as a challenge that the Soviet regime could take over and transform into a socialist art-form. Opera served as a form of legitimization of power, a symbol of prestige, a variant of 'bread and circuses', with political elitism going hand in hand with cultural elitism as part of the mystique of power. In other societies such relationship was usually between politics and religion. In Soviet Russia art seems to have taken the place of religion as a legitimization device. Moreover, Soviet opera was charged with symbolic meaning. The Bolshoi Theater represented the state power of the Bolsheviks. The staging of operas coincided with party congresses and big international events such as Comintern Congresses. The Bolshoi Theater's position near the Kremlin and near the main city prospects (Prospect Marksa with the statue of Marx and Engels on the opposite side) also contributed to the image of the Bolshoi Theater as the crux of High Soviet Culture. In this sense the Bolshoi Theater was appropriated as a symbol of continuity between the best achievement of the Tsarist period and Soviet Russia amalgamated with the greatest masterpieces of European composers and musicians.

The only problem that remained unsolved was creation of an ideal contemporary Soviet opera, which could be staged at Bolshoi Theater and later transferred to all existing opera stages in the Soviet Union. The general cultural aim of the period was the appliance of Socialist Realism ${ }^{13}$ to opera theater. What the government demanded then was the creation of 'socialist realist' opera, but what exactly this meant was not clearly formulated in words.

Already in 1928 Lunačarskij criticized the Bolshoi Theater and its repertoire politics for 'passiveness, ghastliness, and laziness that prevent the appearance of new productions: senile ossification, compact opposition to the questions of energetic movements of the theater towards a new repertoire and towards the promotion of younger forces.' ${ }^{14}$

The Union of Soviet Composers was progressively established after the Party's Resolution of April 1932 'O perestrojke literaturno-xudožestvennyx

13. The first Congress of the Soviet writers took place in 1934, and proclaimed the new creative doctrine - 'socialist realism'. At the Congress, Ždanov defined the aims of Socialist Realism, 'to depict reality in its revolutionary development' and he called for 'works attuned to the epoch.' (A. Ždanov, Essays on Literature, Philosophy, and Music, New York, 1950, p. 7-15). A year earlier, in 1933, Gor'kij had published an essay, On Socialist Realism, which provided a basic definition of this new concept (M. Gor'kij, О соииалистическом реализме, Moskva, 1933).

14. « От слов к делу », Современный театр, Moskva, Teatr-kino-pečat' 1927-1929, no. 21, 22 May 1928, p. 405. 
organizacij'. The first to be organized were groups in Moscow and Leningrad followed by republican unions of Ukraine, Byelorussia, Georgia, and Armenia. In 1932 the Soviet composers were in a state of tension, as the model Soviet opera has not yet been created. The attempts to switch to a 'Soviet thematic' were not considered satisfactory by party critics.

The Composer's Union established the journal Sovetskaja muzyka in 1933. The first issue of Sovetskaja muzyka carried an article by the critic Gorodinskij entitled 'On the Problem of Socialist Realism in Music', which really was a problem, since it was by no means clear how to convert this literary term into the musical realm:

The main attention of the Soviet composer must be directed towards the victorious progressive principles of reality, towards all that is heroic, bright, and beautiful. [...] Socialist Realism demands a pitiless struggle against folk-negating, modernistic directions that are typical of the decay of contemporary bourgeois art and against subservience and servility towards modern bourgeois culture. ${ }^{15}$

Thus, already in this article Socialist Realism and Formalism became the two opposing concepts from the early 1930s. ${ }^{16}$

The main expectations for the production of the ideal 'socialist opera' were connected with the Bolshoi Theater, which gradually raised above all the other opera theaters in the USSR. In 1930 it was officially placed under the jurisdiction of CIK, ${ }^{17}$ which gave it a similar status to that of the court theater during Tsarist times. By the decision of the Politburo on 15 May 1930: 'The Bolshoi Theater with its filials and all enterprises are to be put under the jurisdiction of CIK USSR.' ${ }^{18}$

Thereafter the Bolshoi Theater had no financial problems, as it received money directly from the Reserved Fund of Sovnarkom (The Council of People's Commissars). For example, in August 1931 the Politburo allocated 400,000 rubles

15. From « Statues of Composers Union », quoted in Энииклопедический музыкальный словарь, Moskva, 1966, article « Социалистический Реализм », translation from Boris Schwarz, Music and musical life in Soviet Russia, 1917-1970, London, Norton, 1971, p. 223.

16. See: Gary Saul Morson, « Socialist Realism and literary Theory», The Journal of aesthetics and art criticism, vol. 38, no. 2 (Winter, 1979), p. 121-133; Victor Terras, « Phenomenological Observations on the Aesthetics of Socialist Realism ", The Slavic and East European Journal, vol. 23, no. 4 (Winter, 1979), p. 445-457; Barbara Makanowitzky, « Music to serve the state», Russian Review, vol. 24, no. 3 (Jul., 1965), p. 266-277.

17. CIK - Central Executive Committee was the body responsible for the policy of Soviets between meetings of the Soviet congress. There were two well known executive committees: the All-Russian Central Executive Commitee (1917-1922) and the All-Soviet Central Executive Committee (1923-1991). The central executive committee was initially freely elected by the members of the Soviet, but by the 1930s the membership became fully controlled by the Politburo. See Charles Duval, Central Executive Committee of the USSR, in: Joseph L. Wieczynski, ed., The Modern Encyclopedia of Russian and Soviet History, Academic International Press, vol. 6, 1978, p. 170-172.

18. RGASPI (Rossijskij gosudarstvennyj arxiv social'no-političeskoj istorii), F. 74, op. 1, delo 785, Meeting of Politburo the 15 May 1930. 
for the construction of the Lenin Library, and 200,000 rubles to cover the deficit of the Bolshoi Theater. ${ }^{19}$ In November 1931 from the same fund 346,000 rubles was provided to cover the theater deficit for the $1931^{20}$ season. Thus, one season of the Bolshoi Theater cost more than the erection of the Lenin Library.

In 1934 the Politburo decided in a special session to raise the salaries of the Bolshoi staff:

Decision: to accept the proposal of comrade Enukidze about raising the salaries of all the categories of Bolshoi employees, assigning for the yearly fund of salary an additional 1.491 .684 rubles. ${ }^{21}$

This new decisive attempt to organize the activity of the Bolshoi Theater was undertaken in spring-summer 1935. On 26 April 1935 the Politburo abolished the Commission at CIK, which supervised the activities of the Bolshoi Theater. Future 'oversight' of the Bolshoi and Moscow Art Theater was entrusted, instead, to I. A. Akulov, Soviet chief Procurator in 1933-1935, and of the other theaters to A. S. Bubnov, People's Commissar of Enlightenment in 1929-1937. ${ }^{22}$ Akulov was relieved as Procurator in March 1935, and was immediately appointed secretary of CIK, replacing Enukidze. So CIK still controlled the Bolshoi and Moscow Art Theaters. Enukidze was Stalin's family friend, godfather of Stalin's second wife Nadežda Allilueva and witness of their marriage. In 1935 Enukidze fell out of Stalin's favor. Historian Henry Lane Hull suggests that 'Enukidze was eliminated because he knew too much about Stalin's background and the reasons for the terror, as well as for his own opposition to it. He had interceded on behalf of some of the accused and appears to have taken up many of their causes with those in authority. ${ }^{23}$ This suggests that CIK under Enukidze was viewed by Stalin as being ideologically unreliable. This might be seen also as part of Stalin's dissatisfaction with CIK's management of cultural policy. The fact that other theaters were transferred to be controlled by Bubnov, head of Narkompros, clearly indicated a deep dissatisfaction with the work of CIK. Under control of Enukidze the musical modernists - such as Šostakovič - were being protected up to 1935 . The ouster of Enukidze was a sign that that protection was over.

Before 1936 Šostakovič was one of the most frequently performed contemporary composers in the Bolshoi Theater. According to the musicologist

19. RGASPI, F. 74, op. 1, delo 845.

20. RGASPI, F. 74, op. 1, delo 860.

21. RGASPI, F. 74, op. 1, delo 944, Politburo meeting 26 April 1934.

22. RGASPI, F. 74, op. 1, delo 962, Politburo meeting 26 April 1935.

23. Henry Lane Hull, «Enukidze, Avel’ Safronovich », in: Joseph L. Wieczynski, ed., the Modern Encyclopedia of Russian and Soviet history, Gulf Breeze, Fl., Academic International Press, vol. 10, 1979, p. 206-209. 
E. Vlasova, who studied the repertoire books of the Bolshoi Theater for 1930s, there were 6-7 performances on Šostakovič music monthly, thus his ballet and operas were performed every 4-5 days. ${ }^{24}$ This was still considered not enough for the repertoire of the Bolshoi Theater, since in the autumn of 1935 there was opened a new campaign of criticism of the Bolshoi Theater. There appeared the articles in the newspaper Sovetskij artist, organ of Politbureau, Local trade union committee, Committee of Komsomol and the Directorate of the Bolshoi Theater, with the following headings: 'Youth Does Not Work Enough in the Bolshoi!', 'Theater is not a Museum', 'Towards the Rebirth of Realistic Stage Design', 'Against Imperial Kitsch', etc. ${ }^{25}$ These articles accused the recent Bolshoi Theater of being too old-fashioned, too pompous, while Soviet art should be realistic and simple at the same time. It stressed the fact that the young generation and the youthful approach to the productions should succeed the old, Tsarist hangovers. This short campaign then culminated in September in the slogan: 'Struggle for Repertoire Plan is the Task of the Whole Collective', and the article signed by the Bolshoi director, Mutnyx, who revived the maxim: 'Special Attention to Soviet Operas!' 26

Stalin himself paid attention to the processes of creation of the 'socialist opera', which seemed to be unsuccessful so far. Contrary to common opinion, Stalin did not visit the Bolshoi Theater very often. ${ }^{27}$ And the fact that he paid two visits in one month period to contemporary opera productions staged at the Bolshoi Theater showed how important the elaboration of Soviet opera seemed to him at that moment.

On the evening 17 January 1936 Stalin - accompanied by Molotov and Bubnov - attended a performance of an opera by a young composer, Ivan Dzeržinskij, The Quiet Don, based on Šoloxov's novel. It was performed by Malegot ${ }^{28}$ touring in Moscow. Here was a work that seemed to fill all the requirements of the 'new' Soviet opera: it was simple, healthy, socialist, and patriotic.

On 21 January 1936 Pravda reported that Stalin was favorably impressed by The Quiet Don. Obviously, it represented a type of opera to be patronized officially.

24. E. S. Vlasova, 1948 год в советской музыке, Moskva, Klassika-XXI, 2010, p. 165.

25. Советский артист, no.26 (45), 30 September 1935, p. 1.

26. Ibid.

27. The Museum of the Bolshoi Theater preserves the release issued on Stalin's visits to the Bolshoi Theater from 1937 till 1953. Surprisingly enough, there were only four occasions recorded there: 7 December, 1937 - Borodin's Kniaz' Igor', 20 September, 1939 - again Kniaz' Igor', but in the company of Vorošilov and Molotov, 12 November, 1939 - Čajkovskij's The Queen of Spades with Molotov, and 20 February, 1953 - Asafev's ballet The Flame of Paris (Governmental file from the Museum Archive of the Bolshoi Theater, p. 4).

28. Malegot - Malyj Leningradskij opernyj teatr. 
Dzeržinskij and the conductor Samosud reported in their own words what had been said during the conversation, thus unconsciously formulating the main task of the Soviet opera theater for the next two decades:

Comrade Stalin said that the time was ripe for the creation of a classical Soviet opera. He pointed out that such an opera should be emotionally inspiring, and that melodic inflections of folk music should be widely used. The music ought to make use of all the latest devices of musical techniques, but its idioms should be close to the masses, clear and accessible. ${ }^{29}$

Stalin also said to Samosud that while operatic classicism was needed, it was time to have our own Soviet classicism, which should be the concern of all people active in Soviet music.

December 1935 and January 1936 were crucial turning point in opera policy. It was signaled by turning the Sector of Arts of Narkompros into an independent body - The Committee for Artistic Affairs (further in the text CAA, Komitet po delam iskusstv) attached to the Council of Peoples Commissars USSR. The responsibility for creating CAA belonged to Stalin. On 16 December 1935 he presented his project for CAA to the Politburo. The CAA should: 'manage all the affairs of the arts, subordinating to it theaters and other spectacle institutions, cinema organizations, musical, fine arts, sculpture enterprises and other enterprises that educate the professionals of theater, cinema, music, and fine arts.' ${ }^{30}$ Musicologist Marina Frolova-Walker argues that CAA was created in order to 'ensure that the arts are much more tightly controlled than before'. ${ }^{31}$ Although this statement is correct, the role of CAA was not only to control, but to invest. CAA was organized primarily in order to distribute monetary support to theatrical activities at, first and foremost, the local level, which showed the distribution of finances:

1) For the education of professionals $7,830,000$ rubles

2) For the development of the arts of the peoples of the USSR 1,900,000 rubles

3) For the organization of symphonic orchestras and choral groups $1,780,000$ rubles

4) For the organization of exhibitions and pictures buying for the state $2,650,000$ rubles

5) For administrative needs $1,515,000$ rubles. ${ }^{32}$

29. Ленинградская правда, 24 January 1936, translated in: Boris Schwarz, Music and musical life in Soviet Russia, 1917-1970, London, Norton, 1971, p. 144-145.

30. RGASPI, F. 74, op. 1, delo 973, Politburo meeting 16 December 1935.

31. Marina Frolova-Walker, «The Soviet Opera project: Ivan Dzerzhinsky vs. Ivan Susanin », Cambridge opera journal, 2006, vol.18, 2, p. 192.

32. RGASPI, F. 74, op. 1, delo 980, Politburo meeting 1 September 1936. 
This budget proves a huge investment of finances into the musical activities of the USSR, and opera primarily, because it was considered to be the top in the hierarchy of the musical genres. The common opinion of Soviet musicologists and officials by the end of 1930s considered opera to be the most developed and the most complicated form of music. In the public discussion within the Composers Union, in the anonymous articles published in various newspapers of the time there was many time clearly stated that the level of the operatic development showed the general level of music culture of every nation. Thus, it is not surprising that one of the first measures undertaken by Platon Keržencev, the newly appointed chief of CAA, was the control over the repertoire of the Bolshoi Theater. The request for the repertoire of the Bolshoi was sent by Keržencev to Mutnyx on the 20 of January 1936 in order to arrange Stalin's visit to the theater to see opera by Šostakovič premiered in the Bolshoi about a year ago, long after a glorious Leningrad premiere. This visit was not made of pure curiosity. Newly 'discovered' Dzeržinskij was heavily criticized by his fellow composers for being almost musically illiterate and employing primitive language in his music. ${ }^{33}$ Contrary to this, Lady Macbeth aroused international interest. Stockholm, Prague, London, Ljubljana, Zürich, Copenhagen performed the work in 1935-1936. In Russia by 1936 there had been eighty-three performances in Leningrad and ninety-seven in Moscow. The piano scores, with Russian and English texts, were published by Muzgiz (Musical State Publisher) in 1935. Šostakovič might well be considered as one of the possible creators of the model Soviet opera, which was urgently demanded.

On 27 January 1936 Stalin saw Lady Macbeth of Mtsensk in a Bolshoi production and found it disgusting. On 28 January Pravda published an article Muddle instead of Music (Sumbur vmesto muzyki). It was followed a week later (6 February) by a second article, directed against the ballet The Limpid Stream (Svetlyj ručej). Both articles were unsigned, but they undoubtedly had the standing of official policy pronouncements.

Indeed, nothing could be further from an idyllic concept of contemporary Soviet opera than Šostakovič's erotic drama, based on a story of murder, greed, and lust. Šostakovič took Leskov's classical story, Lady Macbeth of Mtsensk (Ledi Makbet Mcenskogo uezda), reshaping it into a psychological erotic drama with socio-critical overtones, and providing it with a score of modern expressionism (Šostakovič's Lady is a contemporary of Berg's Lulu), in turn glowing, crude, satirical, and impassioned. Šostakovič's opera combines colossal talent with the open expression of base passions. In Katerina Izmajlova herself there is almost nothing of the positive heroine. Her passion drew her into the depths

33. See more on Dzeržinskij's music criticism Frolova-Walker, «The Soviet opera project... », p. 181-216. 
of the subconscious and her last monologue, about the black lake, left no hope whatsoever and confirmed the victory of the forces of evil. ${ }^{34}$

The attack on Šostakovič was made not just on the grounds of modernism. The Pravda article had three references to 'leftist' distortions and confusions. This implies an ideological deviation. Leftist was usually associated with Trotskyist. The combination of modernism and leftism was therefore very significant and potentially very threatening. But a close scrutiny of the article, Muddle instead of music, shows too many signs of it having been written in a hurry and of lacking well-thought out argument for it to have been a programmed and planned statement on the part of the regime. Even if one is to cast aside the typically - for the age - coarse language in which it is couched, the reproaches hurled against Šostakovič are so numerous and, more important, confused, that they indicate the spontaneity of the publication and show that its author, whoever he may have been, was in a rage.

With Lady Macbeth, Šostakovič, the Soviet Union's first composer, destroyed the regime's and Stalin's, highly-cherished dream of a Soviet classical opera with a positive, contemporary hero. Ideologists were naturally worried by the fact that Šostakovič's 'immoral' and cheerless opera had received unqualified praise from just about everyone in music, and from a section of the political elite and from opera houses abroad. Thus, the ideal Soviet opera was still badly wanted, but from 1936 onwards the governmental aspiration for its creation was no longer connected only with the Bolshoi Theater.

\section{DEKADY AS SEARCH ENGINE FOR THE MODEL SOVIET OPERA}

In 1936 the new initiative was presented by CAA: Dekady of National Art. Dekady were dedicated to the arts of one of the Soviet republics: opera and ballet, art and folk music performances by orchestras, composers, and artists. Sometimes they were synchronized with exhibitions of painting and sculpture, dramatic performances, or national literature readings. From 1936 to $1953,{ }^{35}$

34. For analysis of the opera, and the two versions of the opera and also its fate: Jeremy Noble, The two versions of Lady Macbeth, San Francisco, Performing Arts Network, 1981; Patrict T. J. McPhee, The Effects of state censorship on the development of compositional style: the case of Dmitri Shostakovitch and Lady MacBeth of Mtsensk District, [Waterloo, Ont.: s.n.], 1989; April McNeely-Zissman, Biography of an opera: Lady Macbeth of Mtsensk by Dmitri Shostakovitch, Thesis (M. A. in Music), Calif. State University, East Bay, 2006; Boris Schwarz, Malcolm Hamrick Brown, Russian and Soviet music: essays for Boris Schwarz, Ann Arbor, Mich., UMI Research Press, 1984; David Fanning, Shostakovitch studies, Cambridge-New York, N.Y, Cambridge University Press, 1995.

35. March 1936 - Ukraine, May 1936 - Kazakhstan, January 1937 - Georgia, May 1937 Uzbekistan, April 1938 - Azerbaijan, May-June 1939 - Kyrgyzstan, October 1939 - Armenia, May 1940 - Leningrad, June 1940 - Byelorussia, October 1940 - Buryat-Mongolia, April 1941 - Tajikistan. After a ten year interruption owing to war and post-war conditions, the Dekady were resumed in 1951, June 1951 - Ukraine, and November 1951 - Uzbekistan. 
thirteen Dekady were presented, showing the arts of Ukraine, Kazakhstan, Georgia, Uzbekistan, Azerbaijan, Kyrgyzstan, Armenia, Leningrad, Byelorussia, Buryat-Mongolia, Tajikistan - before the war, and Ukraine and Uzbekistan from 1945 to 1953. Opera and ballet productions were performed in the Bolshoi Theater. Only some of these regions had old musical traditions, for example the Ukraine, Georgia, Azerbaijan, and Armenia. But there were also regions where, before the Soviet era, no written musical notation had existed, and in creating national operatic and musical culture the reliance was on oral traditions. In such musically underdeveloped regions opera culture was implanted by the Soviet government, opera houses were built and opera singers were trained. In1929 state Uzbek national musical theater was opened in Tashkent, in 1930 - Kyrgyz state theater - in Frunze (transformed into musical-dramatic theater in 1936), in 1933 - Kazakh national opera house was opened in Alma-Ata, Armenian state opera theater in Yerevan, Byelorussian state opera theater in Minsk, in 1939 musical-dramatic theater in Ulan-Ude, in 1940 - state opera theater in Dushanbe. Composers were sent from Moscow and Leningrad in order to help the national cadres write their national operas which were to be shown during the Dekady. R. Glier worked in Uzbekistan, V. Vlasov, V. Fere, and A. Veprik - in Kyrgyzstan, and A. Kozlovskij - in Uzbekistan, E. Brusilovskij - in Kazakhstan, A. Lenskij - in Tadzhikistan, and so on.

In her article on music nation-building in the Soviet republics, Marina Frolova-Walker pointed out that the power wanted to implement the norms of the 19th century Russian operatic romanticism to the operas of the distant regions. ${ }^{36}$ And that the phenomenon of sending Russian composers to the regions was based on the desire to get production 'national in form and socialist in content' in the republics. ${ }^{37}$ Indeed, Dekady were institutionalized in order to demonstrate Stalin's thesis of the flourishing of the culture of diverse nationalities and to control its development. The very idea of decades fitted very much into the Soviet concept of cultural geo-politics, which aimed at the creation of a General Soviet culture and 'new Soviet classics'. ${ }^{38}$

But the very idea of the Dekady project was originally broader than demonstration of opera productions of 'sister republics' at the stage of the Bolshoi Theater. The Dekady of national art was only a part of it. It aimed the whole country and was supposed to provide musical exchange between all the republics,

36. Frolova-Walker, «'National in form, socialist in content': musical nation-building in the Soviet Republics » Journal of American Musicological Society, vol. 51, no. 2 (Summer 1998), p. 331-371.

37. In January 1934 Советская музыка for the first time published Stalin's slogan 'The Development of cultures: national in form and socialist in content' and applied it to music.

38. 'The development of cultures national in form and socialist in content is necessary for the purpose of their ultimate fusion into the General Culture, socialist in form and content, and expressed in one general language.' (I. Stalin, Марксизм и начиональный вопрос, Moskva, 1934, p. 195). 
so that music composed, for example, in Georgia could be heard the next or the same year in Byelorussia, and Ukraine, and vice versa. From 1937 onwards, apart from the national republican Dekady in the Bolshoi Theater, the Dekady of contemporary music, which sometimes lasted for up to 30 days, were organized by CAA. ${ }^{39}$ Already the first Dekada of contemporary music was criticized for the lack of opera productions among the presented contemporary compositions, and at the second in 1938 this shortcoming was changed. The concerts of the first Dekada of contemporary music took place in Moscow, Leningrad, Minsk, Kiev, Tbilisi, and also Sverdlovsk, Rostov, Kharkov, Odessa. The Dekada of contemporary music lasted for the whole month in Tbilisi. Attendance of the Dekada exceeded the quotas over $117.2 \%$, and profitability over $141.5 \%$.

Keržencev, who also took part in the discussion expressed the harshest criticism and pointed out the desired direction for the development of the future Dekady. He said:

What is the strongest defect of the Dekada? That we could not show quite representatively Georgian or Armenian (except Xačaturjan), or Byelorussian music in Moscow, and so on. And Ukrainians did not play Russian or Georgian music. And in Georgia very little Byelorussian or Russian music was performed. And so on. There was no organic exchange of national music. Moscow Dekada remained just the Dekada of Russia, Leningrad - just of Leningrad music. Georgians showed only their music, which was interesting. And so did the Ukrainians. This limitedness of our Dekada in presentation the national music is the chief shortcoming. ${ }^{40}$

The same rhetoric surrounded every national Dekada, when the operas 'national in form', but composed by Russian composers together with one national 'cadre' (normally educated in Moscow or Leningrad conservatory and responsible for national, mostly oriental melodic flavor in the operas), were performed in the Bolshoi Theater as an example of local achievements. In the official discourses it was stated that the composers could learn something from the nations they were composing the first operas to. Although it is proved that the Soviet attitude towards the republics was pure Kulturträger and, thus, colonial one, the ambitions of the power went further. The republics were ultimately to teach the center. The only hope remained that in the republics, at the "virgin musical soil' of Buryat-Mongolia or Kyrgyzstan, there still could be made some achievements in creating the desired Soviet classical opera, which the Bolshoi Theater with its traditions and high culture had obviously failed to create as highlighted by the Lady Macbeth debacle in 1936.

39. RGALI (Rossijskij gosudarstvennyj arxiv literatury i iskusstva), F. 962, op. 3, delo 314, Совещание у Тов. Керженцева о результатах декады советской музыки, 9 December 1937.

40. Ibid. 
The Dekady of national art, as well as the Dekady of contemporary music serve as examples for the building of the common Soviet cultural identity, fusing elements of high musical European culture and Asian musical practices. The initial cultural concept of the young Soviet state during Lenin's times was unambiguously European, with the denial of anything Asian as 'backward', 'dark', and 'underdeveloped'. But already after 1924, when thesis of 'socialism in one country' was elaborated and adopted by Stalin's government, it became clear that Stalin should make sense of the huge Asian part of this very country. Stalin perceived himself as a ruler of the European and Asian parts of the USSR, and both were equally significant to him. Moreover, he aimed to put into practice his own project of creation truly homogeneous state. He did so not only by means of force, but by more 'soft' methods of cultural influence by creating the Soviet classical culture, common for the whole territory of the Soviet Union and common for all its peoples.

The establishment of the classical opera enterprises was not only the best way to equalize the previously culturally deprived republics with the most cultural ones. Opera was an appropriate genre to establish the socialist-realist canon in music and to transmit it to the whole territory of the Soviet Union. Stalin himself had some ideas of how the model contemporary opera should look like, which he desired to listen in the Bolshoi Theater and all over the country. Once he said that 'we need our Soviet classics, like the 19th century classics, but better'. Stalin listed its desirable basic attributes - a libretto with a Socialist topic, a realistic musical language with stress on national idiom, and a positive hero typifying the new Socialist era. These criteria were submitted to a group of opera composers, critics and directors at a meeting of 17 January 1936. Thus, all newly composed operas in the republics had to follow this model.

Thus, in the famous phrase 'art national in form, socialist in content,' content was much more important that the form. Not only the Stalinist government was not afraid of the manifestation of national character in music, it supported it unless it served to the higher purpose of creating the opera art socialist in substance. Stalin's imperial politics was broader and deeper than Russification. This was the dissimilation of ideologically approved classical culture, which the Stalinist state associated itself with, to the territory of the whole country. As most of the authoritarian leaders of 20th century, Stalin wanted to build his state for centuries. In the republics this classical art composed and performed according to the social-realist canon would create certain consciousness and taste of the population, which in the future could unite all Soviet peoples at a more solid basis than Russian language. 